\title{
OBRAZ ŚMIERCI CZŁOWIEKA W POSOBOROWEJ LITURGII
}

Kościół na poszczególnych etapach swoich dziejów coraz głębiej wnikał w tajemnicę eschatycznej rzeczywistości, by odpowiadać na duchowe potrzeby, tęsknoty i niepokoje człowieka. Przejawem tej troski jest, odnowiona po Vaticanum II, liturgia pogrzebowa za zmarłych, pomagająca człowiekowi w zmierzeniu się z doświadczeniem śmierci, które zawsze jest bolesne i rodzi wiele pytań.

Nauka Kościoła dotycząca rzeczywistości eschatycznych nie zmieniała się co do istoty, chociaż niektóre jej aspekty podlegały pewnej ewolucji, która widoczna jest między innymi w obowiązujących obecnie tekstach liturgii za zmarłych. Wskazują one, że ludzka śmierć i perspektywa wieczności są tematami wciąż aktualnymi, bo związanymi z najgłębszą tajemnicą, a zarazem nadzieją człowieka. W naturze ludzkiej zakodowana jest bowiem tęsknota do wiecznego trwania, a życiowa aktywność człowieka świadczy o dążeniu bytu ludzkiego do zjednoczenia z Bytem Transcendentalnym - Bogiem. On bowiem stanowi rację ostateczną ludzkiego bytowania i jest gwarantem nieprzemijalności człowieka.

Kościół wychodzi naprzeciw duchowych potrzeb człowieka, wpływa na kształtowanie jego postawy wobec choroby, umierania, śmierci oraz pogrzebu. Rzeczywistości te, pomimo znaczącego postępu cywilizacyjnego, technicznego i kulturowego, nieustannie stawiają człowieka wobec fundamentalnych pytań: kim jest i jaki jest cel jego egzystencji. Z pomocą w odpowiedzi na te pytania przychodzi 
soborowa Konstytucja duszpasterska o Kościele w świecie współczesnym Gaudium et spes, w której czytamy: „W obliczu śmierci najwyraźniej ujawnia się tajemnica ludzkiego istnienia. Człowiek doznaje nie tylko bólu i postępującego rozpadu ciała, lecz także, w jeszcze większym stopniu, lęku przed wieczną zagładą. (...) Wszelkie wysiłki techniki, chociaż bardzo pożyteczne, nie są zdolne uśmierzyć niepokoju człowieka, bowiem przedłużenie długowieczności biologicznej nie może zaspokoić pragnienia dłuższego życia, które nieprzezwyciężenie tkwi w jego sercu." (KDK 18).

Prezentowany artykuł - oparty na analizie wybranych tekstów Mszy za zmarłych - stawia sobie za cel pogłębienie refleksji zarówno nad misterium śmierci, jak i pełnym nadziei oczekiwaniem na eschatologiczną przyszłość.

\section{MODLITWY MSZALNE ZA ZMAREYCH}

Mszał rzymski dla diecezji polskich - co warto podkreślić - różni się od Mszału rzymskiego łacińskiego pod względem liczby zestawów, zawiera bowiem trzy kolekty: za poległych w obronie ojczyzny, za zmarłego ojca rodziny i za zmarłą matkę rodziny, których nie ma w Mszale łacińskim. Odpowiednikami formularza łacińskiego Pro parentibus są w Mszale polskim dwa formularze - modlitwy za zmarłych rodziców celebransa oraz modlitwy za zmarłych rodziców.

W modlitwach mszalnych za zmarłych Mszału Pawła VI prośby mają charakter konkretny, ponieważ dotyczą określonych zmarłych i odnoszą się do ich stanu, powołania, sytuacji życiowej. Można wśród tych modlitw wyróżnić dwie grupy: szczegółowe modlitwy za zmarłych, chciałoby się rzec - imienne, oraz modlitwy ogólne za wszystkich zmarłych. Do pierwszej grupy należy większość formularzy: trzy za zmarłego papieża, po jednym za biskupa diecezji i za innego biskupa lub kardynała, dwa za zmarłego kapłana, jeden za zmarłego diakona, jeden za zmarłych rodziców celebransa (Mszał dla diecezji polskich), a także po jednym za zmarłych rodziców i za zmarłych krewnych, przyjaciół i dobrodziejów. W swojej treści modlitwy te nawiązują do ziemskich funkcji pełnionych przez 
zmarłego. Na przykład Kolekta pierwszego formularza Mszy za zmarłego papieża (MR 897/MRP 221'”), akcentuje znaczenie jego wierności wobec Boga. Modlitwa wspomina papieża jako tego, który za życia był wiernym szafarzem Bożej łaski i miłosierdzia. Kolekta trzeciego formularza Mszy za zmarłego papieża (MR 898/MRP 223”) eksponuje natomiast fakt jedności zmarłego z Kościołem na ziemi oraz jedności z powierzonym mu ludem w wiecznej radości.

Do drugiej grupy modlitw mszalnych za zmarłych należą trzy formularze za jednego zmarłego i trzy formularze za wielu zmarłych.

Kilka formularzy zawiera same kolekty. Są to modlitwy za zmarłego zakonnika lub zakonnicę, za zmarłych w młodym wieku, za zmarłych, którzy pracowali w służbie Ewangelii, za zmarłych po długiej chorobie, za zmarłych w obronie ojczyzny (Mszał dla diecezji polskich), za zmarłych nagle, za zmarłych małżonków, za zmarłego ojca rodziny oraz zmarłą matkę rodziny (obydwie - w Mszale dla diecezji polskich).

Wiele modlitw koncentruje się na jednej wybranej prawdzie, konfrontując jej realizację w ziemskim życiu zmarłego z Bożą perspektywą. Formularze w zasadzie nie nawiązują wprost do prawdy o zmartwychwstaniu, często natomiast posługują się określeniem „pełnia szczęścia”, które odnosi się do obietnicy zmartwychwstania.

Niektóre z modlitw wyrażają prośby zarówno za umarłych, jak i za żywych, wypraszając na przykład Bożą opiekę dla tych, którzy po odejściu zmarłego pozostają na świecie sami. Przykładem może tu być modlitwa za zmarłą matkę rodziny; Kościół prosi Chrystusa, by zmarła swoją modlitwą wspierała opuszczonych.

Część modlitw formularzy mszalnych za zmarłych wyraża prośbę o odpuszczenie grzechów oraz łaskę przebaczenia dla zmarłego. Teksty te są świadectwem troski Kościoła o losy zmarłych, zwłaszcza tych, którzy po śmierci nie od razu mogą dostąpić pełnego zjednoczenia z Bogiem. Na przykład w Kolekcie trzeciego formularza Mszy za wielu albo za wszystkich zmarłych Kościół prosi: „Miłosierny Boże, w Tobie wierni zmarli znajdują odpoczynek, udziel łaskawie przebaczenia grzechów Twoim sługom i służebnicom N. i N. i wszystkim, którzy zasnęli w Chrystusie, oczyść ich z winy i daj im udział 
w zmartwychwstaniu Chrystusa" (MR 895/MRP 219'). Na troskę Kościoła, wyrażającą się poprzez modlitwę za zmarłych, zwraca uwagę Sobór Watykański II, nauczając: „Kościół pielgrzymów od zarania religii chrześcijańskiej czcił z wielkim pietyzmem pamięć o zmarłych, a <ponieważ świętą i zbawienną jest myślą modlić się za zmarłych, aby zostali uwolnieni od grzechów> $(2$ Mch 12, 46), ofiarowywał za nich modlitwy" (KK 50).

W modlitwie po Komunii Mszy pogrzebowej poza Okresem Wielkanocnym wspólnota prosi: „...oczyść go (ją) z grzechów i daj mu (jej) udział w wiecznej radości zmartwychwstania" (MR 883/MRP 206"), a zatem warunkiem udziału w radości zmartwychwstania jest uwolnienie zmarłego od grzechów. Podobną prośbę w jego intencji zawiera Kolekta formularza modlitw do wyboru Mszy pogrzebowej. Kościół prosi w tej modlitwie o nowe życie i zjednoczenie zmarłego z Chrystusem w chwale, „gdy nadejdzie dzień zmartwychwstania”, co jednak musi być poprzedzone odpuszczeniem zmarłemu wszystkich grzechów. Prosząc o przebaczeniu mu grzechów, Kościół odwołuje się do wiary zmarłego w Zmartwychwstanie Chrystusa.

Modlitwa nad darami Mszy w rocznicę śmierci w Okresie Wielkanocnym przywołuje indywidualne dzieje zbawienia zmarłego: ,... przez sakrament chrztu oczyściłeś Twojego sługę (Twoją służebnicę) N. z grzechu pierworodnego; obmyj go (ją) z własnych grzechów w Krwi Chrystusa (...) i obdarz go (ją) pełnym przebaczeniem" (MR 887/MRP 211"). Modlitwa po Komunii pierwszego formularza Mszy za wielu zmarłych podkreśla, że odpuszczenie grzechów stanowi warunek dostępu do innych dóbr wiecznych: ,(..) udziel swoim zmarłym sługom (służebnicom) odpuszczenia grzechów, aby mogli (mogły) wejść do Twojego Królestwa i chwalić Ciebie na wieki” (MR 906/MRP 233'').

W modlitwach za zmarłych Kościół nie ogranicza się do samych próśb o oczyszczenie z grzechów i uwolnienie od win, ale zawsze ma na uwadze ostateczny cel człowieka, którym jest zjednoczenie z Bogiem. Przykładem tego może być modlitwa po Komunii pierwszego formularza Mszy za zmarłego prezbitera: „(...) spraw, aby w niebie radował się zjednoczeniem z Bogiem" (MR 901/MRP 
226"), a także modlitwa po Komunii drugiego formularza modlitw za zmarłego prezbitera: „,...) pokornie prosimy Cię, Boże, aby Twój sługa, kapłan N. (...) zawsze radował się w Twojej obecności” (MR 902/MRP 226").

Modlitwy za zmarłych Mszału Pawła VI odwołują się do ojcowskiej dobroci Boga, wyrażającej się w przebaczeniu win i oczyszczeniu zmarłego, co podkreśla modlitwa nad darami drugiego formularza Mszy pogrzebowej poza Okresem Wielkanocnym: „(...) w Twojej ojcowskiej dobroci przebacz mu (jej) wszystkie winy i oczyść go (ją) ze wszystkich śladów ludzkiej słabości” (MR 883/MRP 206”).

Należy zwrócić uwagę, że w modlitwach za zmarłych, które odwołują się do miłosierdzia Bożego, zachowany został określony porządek - najpierw zanoszona jest prośba o odpuszczenie grzechów i Boże miłosierdzie, a dopiero potem prośba o zmartwychwstanie i życie wieczne we wspólnocie ze świętymi. Porządek ten odzwierciedla etapy drogi człowieka do osiągania pełni życia wiecznego. Pierwszym z nich jest uwolnienie się od grzechów, które otwiera przed człowiekiem perspektywę życia. W modlitwie po Komunii Mszy w rocznicę śmierci poza okresem wielkanocnym Kościół modli się: „Posileni Najświętszym Sakramentem pokornie prosimy Cię Boże, aby Twój sługa (Twoja służebnica) N. został(a) oczyszczony(a) z wszelkich grzechów”, a gdy dostąpi uwolnienia od nich, by „zmartwychwstał(a) do wiecznego życia" (MR 886/MRP 210").

Wieczność człowieka jest zakorzeniona w jego ziemskich dziejach, jest związana z życiem innych ludzi, co podkreśla pierwsza modlitwa po Komunii trzeciego formularza Mszy za wielu albo za wszystkich zmarłych. Kościół prosi w niej miłosiernego Ojca o przebaczenie grzechów i życie wieczne dla zmarłego, ale także modli się za żywych: „Boże, miłosierny Ojcze, przyjęliśmy Sakrament zbawienia błagamy Cię, aby nam, żyjącym, zapewnił Twoją opiekę" (MR 896/ MRP 220"'). 


\section{MSZE W CZASIE POGRZEBÓW DZIECI}

Modlitwy za zmarłych Mszału Pawła VI nawiązują do sytuacji egzystencjalnych człowieka, czego nie uwzględniała dawna liturgia. Jedną z takich sytuacji jest śmierć dziecka, dlatego nowy Mszał rzymski zawiera teksty przeznaczone na pogrzeby dzieci. Śmierć małego dziecka stała się obecnie zjawiskiem względnie rzadkim, ale może dlatego właśnie ma wyjątkowe znaczenie. W naszym kręgu kulturowym jest przeżywana - nawet przez osoby głęboko wierzące jako wielkie cierpienie'.

Dawny rytuał pogrzebowy ochrzczonych dzieci koncentrował się na aspekcie ich zbawienia, ale stawiał duszpasterza w trudnej sytuacji wobec cierpienia rodziny. Rytuał ten był trudny do przyjęcia i zrozumienia, zwłaszcza dla chrześcijan słabych w wierze. Tym bardziej bolesna była praktyka odmawiania pogrzebu niemowląt zmarłych, zanim zostały ochrzczone. Cierpienie po stracie dziecka potęgowało poczucie opuszczenia czy odrzucenia również przez Kościół².

W wyniku posoborowej odnowy liturgii, sytuacja uległa radykalnej zmianie; Mszał rzymski bowiem w swych formularzach zawiera nie tylko modlitwy za zmarłe dzieci ochrzczone, ale także niechrzczone. Są to trzy formularze Mszy w czasie pogrzebu dzieci: dwa w czasie pogrzebu dziecka ochrzczonego i jeden w czasie pogrzebu dziecka niechrzczonego ${ }^{3}$. Modlitwy te różnią się od modlitw mszalnych za zmarłych dorosłych. Nie zawierają próśb o odpuszczenie grzechów i związane z nim Boże miłosierdzie, ponieważ Kościół modli się za zmarłe dziecko z przeświadczeniem, że dostąpiło już wiecznego szczęścia i przebywa w obecności Boga. Kolekta Mszy w czasie pogrzebu dziecka niechrzczonego wyraża prośbę o umocnienie ufności

1 Por. A. N e 1 i d o w, Rite des funérailles des enfants, w: La maladie et la mort du chrétien dans la liturgie, Roma 1975, s. 229-242.

2 Por. J. D e c y k, Rzeczywistość eschatyczna człowieka wedtug modlitw za zmartych Mszału Rzymskiego Pawła VI, Warszawa 1995, s. 70.

3 Msze w czasie pogrzebu dziecka omawia szczegółowo A. R o g u e t, Messe per le esequie dei bambini, RiL 58(1971) nr 3, s. 408-414. 
w Boże miłosierdzie dla tych, którzy się smucą z powodu tej śmierci. Modlitwa za zmarłe bez chrztu dziecko nie świadczy o zwątpieniu w miłość Bożą ogarniającą to dziecko, ale ma na względzie naturę ludzkiego grzechu, od którego uwalnia człowieka sakrament chrztu ${ }^{4}$.

Wszystkie trzy zestawy modlitw z okazji pogrzebu dzieci wyrażają prośby o pocieszenie dla opłakujących zmarłe dziecko, o umocnienie ich nadziei w życie wieczne dziecka i możliwość spotkania go w wieczności.

\section{MODLITWY EUCHARYSTYCZNE}

Modlitwą, w której liturgia osiąga modlitewny szczyt, jest Modlitwa eucharystyczna, stanowiąca niejako streszczenie wszystkich modlitw euchologijnych. Wprowadza ona wiernych w głębię Bożych tajemnic, które są udziałem uczestników eucharystycznej celebracji. Modlitwa eucharystyczna rozpoczyna się dziękczynnym motywem prefacji. Również prefacje o zmarłych w swoich embolizmach zawierają motyw dziękczynienia nawiązujący do treści eschatologicznych. Wyrażają one dziękczynienie za to, co ma nastąpić, czyli za przyszłość w Jezusie Chrystusie, w której już dziś wierni partycypują poprzez Jego misteria. W strukturę Modlitw eucharystycznych wpisane jest również memento za zmarłych, wskazujące na jego związek z Kościołem, a także z modlitwą wstawienniczą za żywych.

Poniżej zostaną omówione dwie części Modlitw eucharystycznych - prefacje o zmarłych oraz modlitwy wstawiennicze za zmarłych.

\subsection{Prefacje o zmarłych}

Jedną z najbardziej charakterystycznych nowości Mszału Pawła VI - zasługujących na podkreślenie - jest obfitość zawartych w nim prefacji. O ile w Mszale Piusa V było ich tylko szesnaście, o tyle w Mszale rzymskim Pawła VI ich liczba wzrosła do osiemdziesięciu

\footnotetext{
4 Analizę modlitw Mszy w czasie pogrzebu dziecka niechrzczonego przedstawia A. T u r c k, Note sur le finerailles d'efants non baptises, LMD 101(1970), s. 113-118.
} 
jeden. Taka liczba prefacji umożliwiła wiernym stopniowe przyzwyczajanie się do nowych, bogatszych pod względem treści i liczniejszych niż dotychczas formuł. Do czasu opublikowania nowego Mszału Rzymskiego odczuwalny był brak prefacji na zwykłe niedziele. Od XIII w. okazjonalnie w zwykłe niedziele stosowano Prefację o Trójcy Świętej, a używanie tej Prefacji oficjalnie zostało zalecone dopiero w 1759 r. O zapotrzebowaniu na nowe prefacje świadczy fakt, że od początku XIX w. wprowadzano stopniowo nowe formuły (teksty). I tak w 1919 r. do Mszału Rzymskiego została wprowadzona Prefacja o zmarłych. W tym okresie powstały też inne prefacje: o Świętym Józefie (1919), o Chrystusie Królu (1925) i o Najświętszym Sercu Jezusa (1928). Jeszcze przed ukazaniem się Mszału Pawła VI zostały ogłoszone nowe prefacje - na Adwent, na Poświęcenie Kościoła, o Najświętszym Sakramencie oraz na Wszystkich Świętych. W czasie czwartej sesji soborowej Vaticanum II odbyły się celebracje, podczas których zastosowano dwie prefacje - o Duchu Świętym oraz Prefację Mszy ogłoszonej z okazji nadzwyczajnego jubileuszu roku 1965.

W wyniku soborowej reformy liturgii - opartej na dogłębnej analizie starych sakramentarzy i mszałów lokalnych - postanowiono włączyć do Mszału Rzymskiego więcej własnych prefacji o zmarłych. Ich treść koncentruje się na Paschalnym Misterium Chrystusa, które ukazuje chrześcijański wymiar śmierci i nadzieję zmartwychwstania, będące zbawiennym skutkiem śmierci Chrystusa. Po Soborze Watykańskim II Prefacje (prefacje) o zmarłych tworzą w nowym Mszale Rzymskim wspólny blok (pięć prefacji Pro defunctis), umieszczony po sześciu prefacjach zwykłych, a poprzedzający Modlitwy eucharystyczne.

Praktycznie wszystkie prefacje o zmarłych nowego Mszału Rzymskiego mogą być wykorzystywane w każdej Mszy za zmarłych, zarówno w Mszach pogrzebowych, jak i rocznicowych, a także przy odprawianiu egzekwii nad zmarłym dzieckiem ochrzczonym i niechrzczonym oraz dla upamiętnienia rocznicy wszystkich zmarłych ${ }^{5}$.

5 Por. A. Tri a c c a, Per una lettura liturgica dei prefazi (pro defunctis) del nuovo Messale Romano, RiL 58 (1971), nr 3, s. 382 nn. 
Pierwsza Prefacja o zmarłych została włączona do Mszału Rzymskiego przez papieża Benedykta XV w 1919 r. Powszechnie przyjmuje się, że opiera się ona na skorygowanej redakcji starej formuły hiszpańsko-wizygockiej, która znajduje się w wielu źródłach liturgicznych. Uznaje się ponadto, że przeszła ona z warstwy hiszpańsko-wizygockiej do sakramentarzy późniejszych przez tak zwany aż do dziś Dodatek Alkuina. Formułę tę zawierają także źródła ambrozjańskie oraz Mszał Ambrozjański, dlatego można przyjąć, że do Supplemento di Alcuino trafiła dzięki wpływom liturgicznych ksiąg ambrozjańskich. Ze względu na walory eurytmiczne i perfekcyjność stylistyczną tej Prefacji pojawiły się sugestie co do cycerońskiej inspiracji jej tekstu'

Zasadniczą myśl omawianej Prefacji oddaje fragment: „W Nim zabłysła dla nas nadzieja chwalebnego zmartwychwstania i choć nas zasmuca nieunikniona konieczność śmierci, znajdujemy pociechę w obietnicy przyszłej nieśmiertelności. Albowiem życie Twoich wiernych, o Panie, zmienia się, ale się nie kończy i gdy rozpadnie się dom doczesnej pielgrzymki, znajdą przygotowane w niebie wieczne mieszkanie". W części pierwszej Prefacja eksponuje odniesienia chrystologiczne, zaznaczając pośrednictwo Chrystusa. Wyraźnie wskazuje na Misterium Chrystusa jako na źródło ludzkiej nadziei oraz tajemnicę, dzięki której urzeczywistnia się nasze zmartwychwstanie. Treść Prefacji nie akcentuje wyłącznie ludzkiej nadziei i łaskawej przychylności Boga, ale wskazuje na rzeczywistość, która - wprawdzie dopiero zapoczątkowana - zmierza ku pełnemu urzeczywistnieniu?

Druga Prefacja o zmarłych stanowi przeróbkę drugiej części embolizmu pierwotnej Prefacji ambrozjańskiej stosowanej w źródłach ambrozjańskich na dzień powszedni piątego tygodnia In Albis ${ }^{8}$. Zasadniczą myśl Prefacji wyraża zdanie: „On jeden przyjął śmierć, aby nas wszystkich wybawić od śmierci wiecznej i sam umarł na krzyżu,

\footnotetext{
6 Tamże, s. 392-393.

7 Por. A. Ward i, C. Jo h n s o n, The prefaces of the Roman Missal, Roma 1989, s. 499-500.

${ }^{8}$ Por. A. Tri a c c a, Per una lettura liturgica dei prefazi, art. cyt., s. 396.
} 
abyśmy mogli żyć z Tobą na wieki”. Bardziej dosłownie sformułowanie: „ut omnes tibi perpetuo viveremus” należałoby przetłumaczyć: „abyśmy mogli żyć dla Ciebie na wieki”, natomiast Mszał Rzymski dla diecezji polskich używa wyrażenia ,żyć z Tobą”, które jeszcze wyraźniej podkreśla zjednoczenie z Bogiem. Proponowane uściślenie przekładu uwydatnia cel ludzkiego życia jako życia dla Boga9 .

W Mszale Rzymskim dokonano pewnego - inspirowanego racjami teologicznymi - zabiegu, który polega na zamianie terminu voluit (działanie aktywne) na accepit (działanie bierne). Zamiana ta uwydatnia powiązanie dzieła Syna z odwiecznym planem Ojca. Na treść drugiej Prefacji o zmarłych w Mszale Rzymskim wyraźny wpływ wywarły teksty biblijne podkreślające posłuszeństwo Syna wobec Ojca, a także dzieło Syna, którego celem było przyprowadzenie wszystkich ludzi do Ojca. Inspiracje te mogą wypływać między innymi z tekstów 2 Kor 5, 14-15, czy J 11, 50 - gdzie jest mowa o tym, że śmierć jednego człowieka - Chrystusa jest źródłem życia dla wszystkich ${ }^{10}$.

Druga Prefacja o zmarłych podkreśla, że człowiek może osiągnąć życie wieczne we wspólnocie zbawionych tylko dzięki Misterium Śmierci i Zmartwychwstania Chrystusa, który jest jedyną drogą prowadzącą do eschatycznej pełni: „On jeden przyjął śmierć i umarł na krzyżu, abyśmy mogli żyć z Tobą na wieki”.

Embolizm trzeciej Prefacji o zmarłych, pochodzący prawdopodobnie z Sakramentarza z Angouleme, jest najkrótszy i najbardziej wyrazisty ze wszystkich w Mszale Rzymskim: ,Qui est salus mundi, vita hominum, resurrectio mortuorum”- „On jest zbawieniem świata, On jest życiem ludzi, On jest zmartwychwstaniem umarłych". Pomimo podobieństwa, nie ma pewności, że Prefacja ta pochodzi wprost z tego sakramentarza, bowiem podobne frazy można spotkać we wszystkich niemal zachodnich źródłach liturgicznych, wśród których niemałą część stanowią źródła starsze od Sakramentarza z Angouleme,

9 Por. J. D e c y k, Rzeczywistość eschatyczna człowieka, dz. cyt., s. 127.

${ }^{10}$ Por. A. Ward i, C. J o h n s o n, The prefaces, dz. cyt., s. 506. 
a ponadto zwrot ten prawie zawsze występuje w formułach właściwych liturgii za zmarłych ${ }^{11}$.

Zasadniczą ideę trzeciej Prefacji wyraża fragment: „On jest zbawieniem świata. On jest życiem ludzi, On jest zmartwychwstaniem umarłych".

Prefacje czwarta i piąta o zmarłych, pochodzące z Missale Ordinis Praemonstratensis, powstały w wyniku prób rozdzielenia na dwie części ambrozjańskiej Prefacji zawartej we Fragmentum Sancti Mauricii, która znajduje się tylko w starych mszałach ambrozjańskich. Można ją znaleźć we wszystkich drukowanych wydaniach Missale Ambrosianum, z wyjątkiem edycji z 1475 r. i z 1751 r. (wydanie Puteobonellana z 1768 i 1795) oraz z roku 1831 (wydanie kard. Gayarucka) $)^{12}$.

Główną część czwartej Prefacji stanowi passus: „Z Twojej woli się rodzimy, Ty kierujesz naszym życiem i na Twój rozkaz nasze ciało podległe grzechowi wraca do ziemi, z której było wzięte. Zostaliśmy jednak odkupieni przez śmierć Twojego Syna i Ty nas wskrzesisz swoją mocą, abyśmy mieli udział w chwale Jego zmartwychwstania”. Na uwagę zasługuje czas teraźniejszy czasownika excitamur (dosłownie: jesteśmy wskrzeszani), który w Mszale Rzymskim dla diecezji polskich ma formę czasu przyszłego: „Ty nas wskrzesisz”. W tekście łacińskim jest mowa o wskrzeszaniu „teraz”, a zatem frazę: „,tuo nutu excitamur” należałoby przetłumaczyć: „Ty nas wskrzeszasz swoją mocą".

Zasadniczą myśl piątej Prefacji oddaje fragment: „Przez grzech śmierć weszła na świat i wszyscy jej podlegamy, ale Twoja ojcowska miłość sprawiła, że Chrystus nas odkupił, odnosząc zwycięstwo nad śmiercią i powołuje nas do nowego życia”. W polskim tłumaczeniu frazy „cum ipso revocamur ad vitam” został pominięty zwrot „cum ipso" (razem z Nim), jednak tekst łaciński wyraźniej wskazuje na połączenie momentu odkupienia człowieka z Paschą Chrystusa, o której mówi Prefacja.

\footnotetext{
11 Por. A. Tr i a c c a, Per una lettura liturgica dei prefazi, art.cyt., s. 398 n.

12 Tamże, s. $401 \mathrm{n}$.
} 
W treści omówionych prefacji pojawia się motyw dziękczynienia za zbawcze dzieło Boga i jego skutki dla ludzkiego życia, a także motyw łączności Kościoła ziemskiego ze świętymi i aniołami w celu wspólnego składania Bogu dziękczynienia za zbawcze dzieło Chrystusa. W świetle tych prefacji Kościół ukazuje się więc jako społeczność i miejsce spotkania nieba z ziemią.

\subsection{Modlitwy wstawiennicze za zmarłych}

Analizując Memento za zmarłych, będące częścią Modlitwy eucharystycznej, należy najpierw rozstrzygnąć kwestię, czy w Kanonie rzymskim stanowi on tekst pierwotny, czy jest późniejszym tekstem modlitwy orędowniczej, wprowadzanej jedynie w Mszy za zmarłych. W Jerozolimie już w IV w. istniała, znana z katechez mistagogicznych, modlitwa za zmarłych wchodząca w skład Modlitwy eucharystycznej. W modlitwie tej wymieniano patriarchów, proroków, apostołów, męczenników, biskupów i wszystkich, „którzy zasnęli”"13.

Włączenie Memento za zmarłych do Kanonu datuje się od listu Innocentego I (401-417), w którym papież poleca, by imiona przynoszących dary były wymieniane w Kanonie modlitwy eucharystycznej. Oznacza to, że dotychczas były odczytywane w innym momencie celebracji eucharystycznej. W Kościele wschodnim znana była praktyka wypisywania imion na specjalnych tabliczkach zwanych dyptychami. Na Zachodzie również nimi się posługiwano i odczytywano w czasie przygotowania darów, na przykład w liturgii galijskiej na zakończenie obrzędu. Na dyptychach umieszczano imiona żyjących, obecnych i nieobecnych, a także zmarłych. Kościół zachodni kładł jednak większy nacisk na imiona żyjących. Z czasem odczytywanie imion przeniesiono do Kanonu ${ }^{14}$.

13 Por. B. N a d ols k i, Liturgika, t. 4, Eucharystia, Poznań 1992, s. 205.

14 Wpisanie imienia na tabliczce uważano za znak ortodoksji, „,rodzaj kanonizacji”. W Rzymie, w Galii i Hiszpanii dyptychy nazywano „księgami życia”. Tamże, s. 206. 
Prawdopodobnie pierwotnie Memento za zmarłych było wprowadzane do Kanonu jedynie przy okazji Mszy pogrzebowych i rocznicowych, chociaż przez długi okres pomijano je w niedziele i święta, czyli podczas nabożeństw publicznych. Od końca $\mathrm{V}$ w. Kościół czynił generalne wspomnienie o zmarłych w litanii Kyrie, jednak w VIII w., pod wpływem transformacji, stopniowo Memento za zmarłych zaczyna wchodzić w skład struktury Kanonu we wszystkich mszach ${ }^{15}$.

W modlitwie wstawienniczej wierni proszą o wieczną szczęśliwość dla zmarłych, o ich ,udział w Twojej radości, światłości i pokoju”. Rzeczownik, „radość” jest tłumaczeniem łacińskiego refrigerium, które w pierwszych wiekach miało jedynie sens techniczny. Pierwotne znaczenie refrigerare to: orzeźwić za pomocą wody albo cienia, natomiast w sensie moralnym: ochłodzenie kogoś lub czegoś, rozluźnienie, ugaszenie żaru. Chrześcijaństwo dość wcześnie przyswoiło sobie termin refrigerare lub refrigerium na określenie szczęścia niebiańskiego ${ }^{16}$.

Rzeczownik refrigerium - używany w kontekście kultu pogrzebowego - oznacza praktykowane przez chrześcijan uczty pogrzebowe i kommemoratywne. Inskrypcje z przełomu wieków III i IV świadczą o praktykowaniu uczt kommemoratywnych przy grobach biskupów i męczenników. W niektórych regionach biskupi znieśli praktyki tych uczt ze względu na ich związki z tradycją pogańską.

$\mathrm{W}$ analizie terminu refrigerium nie sposób pominąć jego pierwotnego znaczenia - orzeźwienie. Nawet ekskluzywność chrześcijaństwa zachodniego nie wyklucza wpływu ogólnych, rozpowszechnionych w basenie Morza Śródziemnego, koncepcji życia pozagrobowego, odwołującej się do idei orzeźwienia, tak zrozumiałej w panującym tam upalnym klimacie. Termin refrigerium może być zatem użyty dla wyrażenia w przystępnym języku samej istoty szczęścia niebiańskiego. Zresztą, odwoływanie się do tego znaczenia implikuje bogatą symbolikę wody jako źródła orzeźwienia ${ }^{17}$.

\footnotetext{
15 Por. J. J u n g m a n n, Missarum Solemnia, t. 3, Paris 1954, s. 158-169.

16 Por. B. B o t t e, Les plus anciennes formules de priere pour les morts, w: La maladie et la mort du chretien dans la liturgie, Roma 1975, s. 90-93.

17 Tamże.
} 
Istotnym wymiarem modlitwy za zmarłych jest jej piękno rozumiane - zgodnie z Pismem Świętym - nie tylko w kategoriach estetycznych, ale także etycznych. Obrazem tego piękna jest przedstawianie umarłych jako procesji zmierzającej do Boga, co znajduje odzwierciedlenie w napisach nagrobnych z pierwszych wieków chrześcijaństwa. Występujący w nich termin praecessit (odeszli) przywołuje skojarzenia pasyjne.

Liturgia pogrzebowa nawiązuje także do chrztu i to zarówno przez podobieństwa werbalne, jak i symboliczne (paschał, pokropienie wodą). Na uwagę zasługuje określenie śmierci jako snu, pojawiające się już w starożytnych epitafiach: „In somno pacis, hic dormit”. Spoczynek w tradycji chrześcijańskiej jest jednak rozumiany inaczej niż w kulturze pogańskiej, gdzie oznacza bezczynność. W naszym zaś kręgu kulturowym rozumiany jest jako wolność, życie w Bogu, uczestnictwo w mesjańskim wyzwoleniu oraz istnienie w czasach ostatecznych $^{18}$.

Modlitwy eucharystyczne nowego Mszału Rzymskiego zawierają w swojej strukturze modlitwy wstawiennicze i wspomnienie świętych. Eucharystia jest w nich ukazana jako źródło życia Kościoła oraz zadatek przyszłego szczęścia. W historiozbawczej perspektywie przedstawiają one troskę Boga o to, by zgromadzić lud w jednej wspólnocie zbawczej obejmującej wszystkie narody.

Teksty wszystkich modlitw wstawienniczych za zmarłych sprowadzają się właściwie do dawnej Modlitwy eucharystycznej, czyli Kanonu rzymskiego, chociaż niektóre z nich poszerzają swój dotychczasowy zakres.

Pierwsza Modlitwa eucharystyczna wspomina o „sługach i służebnicach, którzy przed nami odeszli ze znakiem wiary i śpią w pokoju”. Za nich oraz za innych zmarłych prosimy: „daj tym zmarłym oraz wszystkim spoczywającym w Chrystusie udział w Twojej radości, światłości i pokoju".

Druga Modlitwa eucharystyczna nawiązuje do chrztu i jego skutków: „Pamiętaj o Twoim słudze, którego (dzisiaj) z tego świata

18 Por. J. D e c y k, Rzeczywistość eschatyczna człowieka, dz. cyt., s. 130. 
wezwałeś do siebie. Spraw, aby ten, który przez chrzest został włączony w śmierć Twojego Syna, miał również udział w Jego zmartwychwstaniu. Pamiętaj także o naszych zmarłych braciach i siostrach, którzy zasnęli z nadzieją zmartwychwstania, i o wszystkich, którzy w Twojej łasce odeszli z tego świata. Dopuść ich do oglądania Twojej światłości”.

Trzecia Modlitwa eucharystyczna również podkreśla znaczenie chrztu i ukazuje perspektywę udziału w Zmartwychwstaniu Chrystusa: „Pamiętaj o Twoim słudze, którego (dzisiaj) z tego świata wezwałeś do siebie. Spraw, aby ten, który przez chrzest został włączony w śmierć Twojego Syna, miał również udział w Jego zmartwychwstaniu, gdy wskrzesi ciała zmarłych z prochu ziemi i upodobni nasze ciało, podległe zniszczeniu, do swojego ciała uwielbionego. Przyjmij również do swojego Królestwa naszych zmarłych braci i siostry oraz wszystkich, którzy w Twojej łasce odeszli z tego świata”.

Czwarta Modlitwa eucharystyczna przywołuje pamięć tych, dla których śmierć była odejściem ze świata w pokoju z Chrystusem, także w ciszy serca: „Pamiętaj także o tych, którzy odeszli z tego świata w pokoju z Chrystusem, oraz o wszystkich zmarłych, których wiarę jedynie Ty znałeś".

Piąta Modlitwa eucharystyczna również mówi o odejściu naszych zmarłych z tego świata w pokoju z Chrystusem oraz o innych zmarłych, których wiarę znał jedynie Bóg: „Pamiętaj także o naszych braciach i siostrach, którzy odeszli z tego świata w pokoju z Chrystusem, i o wszystkich zmarłych, których wiarę jedynie Ty znałeś: Dopuść ich do oglądania Twojej światłości i pełni życia w zmartwychwstaniu".

Pierwsza Modlitwa eucharystyczna o tajemnicy pojednania poleca zmarłych miłosierdziu Bożemu oraz wyraża prośbę dla żywych i umarłych o pomoc w budowaniu Królestwa: „Wspieraj nas we wspólnym budowaniu Twojego Królestwa (...) ze Świętymi (...) i naszymi zmarłymi braćmi i siostrami, których polecamy Twojemu miłosierdziu".

Druga Modlitwa eucharystyczna o tajemnicy pojednania wspomina tych, którzy umarli w Chrystusie oraz zmarłych, których wiarę znał tylko Bóg: „Przyjmij do swego Królestwa naszych braci i siostry, 
którzy zasnęli w Chrystusie, i wszystkich zmarłych, których wiarę jedynie Ty znałeś".

Modlitwy eucharystyczne Mszy z udziałem dzieci zawierają krótkie wezwania: „Za tych, którzy w przyjaźni z Tobą odeszli z tego świata” (pierwsza); „Pamiętaj o tych, którzy umarli i przyjmij ich z miłością do Twojego domu" (druga); trzecia Modlitwa eucharystyczna Mszy z udziałem dzieci nie zawiera wprost modlitwy za zmarłych.

Analizowane modlitwy wstawiennicze za zmarłych podkreślają wspólnotowy wymiar modlącego się Kościoła, akcentują umieranie w pokoju z Chrystusem i wspólne przebywanie zmarłych ze świętymi. Modlitwy wstawiennicze mają zatem charakter wybitnie eklezjalny, bo dotyczą zarówno wierzących, będących członkami widzialnego Kościoła, jak i tych, których wiara znana jest tylko samemu Bogu.

Eklezjalny wymiar widoczny jest również w samej formie Memento, na przykład druga Modlitwa eucharystyczna, wspomina tych, „którzy w Twojej (Bożej) łasce odeszli z tego świata”. W Mszach za zmarłych modlitwa ta obejmuje cały Kościół pielgrzymujący, starający się o oczyszczenie z win, ale również Kościół zbawionych, dlatego w Modlitwie eucharystycznej wymieniane są imiona papieża i biskupa, jest w niej też odwołanie do świętych, szczególnie do Bogurodzicy oraz modlitwa za zmarłych. Modlitwa eucharystyczna urzeczywistnia dzieło zbawienia na ziemi i antycypuje przyszłość, proklamuje skuteczność dzieł zbawczych Boga i Jego obietnic. Wszystkie modlitwy szczegółowe zawierają prośby o przyjście Chrystusa i Jego Królestwa. Cała zatem Modlitwa eucharystyczna jest zorientowana eschatologicznie i ukierunkowana ku wypełnieniu się obietnicy Boga, Paschy Chrystusa i nastania Jego Królestwa. Kościół w modlitwach wstawienniczych za zmarłych ukazuje się jako rodzina, na co wskazuje użycie terminu famulus, który w Mszale Rzymskim dla diecezji polskich został przetłumaczony jako „sługa"19.

\footnotetext{
19 Por. J. J a n i c k i, Misterium Paschalne w Mszale Rzymskim Pawła VI, Warszawa 1992, s. 232.
} 
Wspomnienia żyjących i zmarłych w Modlitwie eucharystycznej należą do grupy modlitw upraszających łaski dla różnych grup wiernych. Połączenie w tych modlitwach wspomnienia żywych i umarłych wyjaśnia ks. S. Czerwik wyjaśnia w taki sposób: „Wspomnienie [zmarłych - przypis autora] łączy się logicznie z poprzednią modlitwą, w której prosiliśmy o owocny udział wiernych w uczcie eucharystycznej. Zmarli nie mogą już obecnie spożywać eucharystycznych darów, ale kiedyś przyjmowali je jako członkowie wspólnoty wierzących. Przez śmierć nie zostali oni odłączeni od Bożej rodziny: są nadal <sługami $>\mathrm{i}<$ służebnicami $>$ Boga, podobnie jak żyjący na ziemi. Kościół sprawujący Eucharystię prosi o te same dobra zbawienia dla zmarłych, w jakich uczestniczą wierni otaczający ołtarz. Zmarli - to ci, którzy przed nami odeszli (dosłownie: wyprzedzili nas) ze znakiem wiary i śpią w pokoju. Życie jest wspólnym pochodem do domu Ojca. Wszyscy idziemy w tym samym kierunku, choć jedni dochodzą do celu wcześniej, drudzy później"20.

\section{TEOLOGICZNE ODNIESIENIA W LITURGII ZA ZMAREYCH}

Właściwy sens zarówno życia, jak i śmierci człowieka można pojąć tylko w świetle wiary w Chrystusa, który umierając na Krzyżu, posłuszny woli Ojca, przemienił i pokonał śmierć poprzez Swoje Zmartwychwstanie w chwale. Zatem śmierć chrześcijanina zyskuje nowe znaczenie w Jezusie Chrystusie, a w Jego umieraniu na Krzyżu objawia się pełnia Bożej miłości.

Wiara chrześcijańska, nauczanie Kościoła, a także teksty liturgiczne przybliżają tajemnice życia wiecznego i zmartwychwstania ciała. Ten przekaz wiary budowany jest w oparciu o wiarę w Chrystusa umarłego i zmartwychwstałego, który jest Zbawicielem człowieka. Poprzez wiarę człowiek poznaje prawdę o własnym zmartwychwstaniu, o której świadczą, wypracowane w ciągu wieków, teksty modlitw

\footnotetext{
${ }^{20}$ S. C z e r w i k, Modlitwa eucharystyczna, w: W. Ś w i e r z a w s k i (red.), Msza Święta. Mysterium Christi, Kraków 1992, s. 274-275.
} 
za zmarłych. Liturgia Kościoła, w wyniku posoborowej reformy, zyskała nowe spojrzenie na rzeczywistość eschatyczną człowieka, podkreślają personalistyczny wymiar życia i śmierci oraz paschalny walor życia chrześcijańskiego, który obejmuje tak życie ziemskie, jak i wieczne, uwieńczone zmartwychwstaniem ${ }^{21}$.

Modlitwy Mszy za zmarłych odznaczają się szczególną intencjonalnością i refleksyjnością. Posiadają wprawdzie cechy wspólne z modlitwami formularzy innych Mszy, ale pod względem treści różnią się od nich, bo ukazują wiernym świat rzeczywistości pozaziemskiej, choć nie pomijają też wydarzeń, sytuacji i postaw właściwych rzeczywistości doczesnej. Już nawet inwokacje wprowadzają w charakter Mszy, a prośby zawarte w modlitwach są wyrazem wiary w moc Paschalnego Misterium Chrystusa, które umacnia nadzieję zwycięstwa nad śmiercią ${ }^{22}$.

Modlitwy podkreślają prawdę, że Eucharystia jest dla człowieka wielkim darem Bożym. Każde spotkanie grzesznego człowieka z Chrystusem, także w Eucharystii, jest wyrazem ludzkiej tęsknoty do pełnego zjednoczenia ze Zbawicielem w wieczności. Zgodnie z treścią modlitw, całe życie zmarłego, w jedności z Bogiem, jest przeznaczone dla Pana. Interpretacja modlitw w aspekcie antropologicznym koncentruje się na człowieku jako osobie. Byt osobowy charakteryzuje się między innymi zdolnością intelektualnego poznania, przeżywania miłości, godnością. W akcie poznania jest on otwarty na odkrycie całej głębi tajemnic bytu, aż po jego ostateczne racje, które odnajduje dzięki poznaniu Boga w prawdzie. Antropologiczny wymiar modlitw ukazuje człowieka jako byt osobowy, religijny, związany z osobowym Bogiem wiekuistym, który jest ostatecznym celem człowieka.

Antropologia chrześcijańska postrzega człowieka jako byt integralny, niepodzielny, związany z osobowym Bogiem wiekuistym. Podobnie - w duchu współczesnej teologii - należy patrzeć na człowieka

${ }^{21}$ Por. M.-D. G o u t i e r r e, Człowiek w obliczu własnej śmierci. Absurd czy zbawienie?, (tłum. z fr. A. K u r y ś), Kraków 2001, s. 174-179.

22 Por. J. D e c y k, Rzeczywistość eschatyczna człowieka, dz. cyt., s. 135. 
w kontekście śmierci. Nie sposób bowiem dzielić go w obliczu śmierci na ciało i duszę, bo umiera cała osoba, czyli integralny, niepodzielny człowiek. Można by się tutaj odwołać do dalekiej analogii ze śmiercią Jezusa Chrystusa, którego także nie sposób podzielić, gdyż na krzyżu umarł jako integralna Osoba. Współczesna teologia skłania się ku takiemu właśnie, personalistycznemu patrzeniu na śmierć człowieka. Ma ono zresztą określone konsekwencje w praktyce duszpasterskiej. Coraz rzadziej słyszymy w kościołach modlitwy „za dusze”, częściej natomiast Kościół modli się „za zmarłego człowieka”. Do takiego przeżywania tajemnicy śmierci prowadzi refleksja nad tekstami Mszy za zmarłych, które wskazują na sens życia ukierunkowanego na cel ostateczny. One też wyznaczają chrześcijańską orientację w przeżywaniu śmierci bliskich, w myśleniu o zmarłych, w modlitwie za nich, a nadto są znakiem łączącym historię przemijającego życia z wiecznością.

Według analizowanych modlitw, ostateczny sens życia człowiek odnajduje w miłości Najwyższego Dobra, jakim jest Bóg. Dzięki temu, śmierć przyjmowana w duchu wiary i nadziei, może stać się najwyższym aktem miłości - oddaniem siebie Bogu. Modlitwy akcentują także godność człowieka jako istoty stworzonej na obraz i podobieństwo Boga, które to odniesienie nadaje sens i nadprzyrodzoną perspektywę ludzkiemu życiu. Modlitwy za zmarłych są pełnym wiary błaganiem o wieczne życie dla zmarłych, opierającym się na głębokim przeświadczeniu, że Bóg nie unicestwia stworzonych bytów.

Stworzony przez Boga świat, uwikłany w grzech, zostanie ostatecznie odnowiony w Jezusie Chrystusie, a człowiek - korona wszystkich stworzeń, będzie się cieszył oglądaniem Boga w wieczności, gdy nastanie nowe niebo i nowa ziemia.

Teksty Mszy za zmarłych zawierają prośby o ich zbawienie, życie wieczne, zmartwychwstanie, udział we wspólnocie świętych, miłosierdzie Boże. Charakterystyczną ich cechą jest odwoływanie się do ziemskiego życia zmarłych, do ich życia sakramentami, do ich modlitwy, do ufności Bogu, życia wiarą, ale i do trudu, który był ich udziałem w ziemskim pielgrzymowaniu. Wszystkie bowiem ziemskie 
zmagania człowieka, przeżywane w łączności z tajemnicami Śmierci i Zmartwychwstania Chrystusa, mają wartość zasługującą dla życia wiecznego, ponieważ są budowaniem już tu na ziemi Królestwa Bożego, którego pełnia nastanie w czasach ostatecznych. Nawiązywanie do tych życiowych okoliczności przypomina prawdę, że eschatologia ma swój wymiar doczesny, choć na ziemi ciągle otwarty na rozwój i dopełnienie. Stworzony przez Boga człowiek jest ze swej natury bytem egzystującym w czasie, a jego wieczność polega na tym, że „przeszłość, teraźniejszość i przyszłość tworzą w uwielbionym Chrystusie jakąś nową syntezę"23.

Bóg urzeczywistnia swój zbawczy plan względem człowieka w konkretnej sytuacji jego ziemskiej egzystencji. Do niej nawiązuje również liturgia za zmarłych, odnosząc się do ludzkiej pracy, przeżywanego cierpienia, zasług, obowiązków stanu czy powołania.

W modlitwach za zmarłych istotny jest również ich aspekt eklezjalny. We wszystkich formularzach modlitw zastosowana została liczba mnoga, co podkreśla wspólnotowy wymiar Kościoła. Zawsze, kiedy kapłan prosi, wielbi, dziękuje - czyni to nie sam, ale cały Kościół, co wspólnota potwierdza, odpowiadając na słowa kapłana aklamacją - „Amen”. Charakter eklezjalny mają też wszystkie formułowane prośby. Kościół, jako wspólnota, modli się za ogół żyjących i zmarłych, co podkreślają wszystkie Modlitwy eucharystyczne we wspomnieniach za żyjących i umarłych.

Charakterystyczną cechą modlitw za zmarłych jest uzasadnienie próśb zanoszonych do Boga. Najczęściej jest nim przynależność zmarłych do wspólnoty Kościoła, dlatego przeważnie jest to modlitwa za wierzących. W niektórych jednak modlitwach eucharystycznych Kościół modli się także za tych, których wiara znana była jedynie Bogu.

${ }^{23}$ Por. P. Gó r a l c z y k, Sens życia, sens śmierci. W petni osobowe spotkanie z Chrystusem, Ząbki 2003, s. 224. 


\section{Streszczenie}

W analizowanych tekstach śmierć człowieka ukazywana jest w powiązaniu ze zbawczymi wydarzeniami Chrystusa, z Jego Misterium Paschalnym, z prawdą o Bożym miłosierdziu, a także z chrześcijańską nadzieją życia wiecznego. Bóg, który wskrzesił z martwych Chrystusa, pragnie bowiem dla grzesznika życia, a nie śmierci.

Teksty liturgii za zmarłych stanowią świadectwo wiary Kościoła w życie wieczne, którego fundamentem jest Jezus Chrystus w misterium Śmierci i Zmartwychwstania. Od chwili chrztu wierzący są w to misterium włączeni, ono towarzyszy ich całemu ziemskiemu życiu aż po dzień śmierci. Do tego faktu nawiązuje także Liturgia Godzin za zmarłych. Kościół otacza zmarłych modlitwą, sprawuje w ich intencji Eucharystię, która głosi śmierć Pana żyjącego: „Ilekroć bowiem spożywacie ten chleb albo pijecie kielich, śmierć Pańską głosicie, aż przyjdzie”. Godne spożywanie Chleba i picie Kielicha jest głoszeniem śmierci Pana, dziś żyjącego, aż powtórnie przyjdzie. Pogłębianie tej więzi dokonuje się poprzez Eucharystię, będącą najdobitniejszym świadectwem miłości Boga do człowieka, ucieleśnionej w Chrystusie.

\section{La mort et les obsèques dans la liturgie après Vatican II Résumé}

L'église est toujours avec l'homme dans son existence jusqu'à la mart. Elle éclaire ça plus profondement par le rituel des obsèques après Vatican II. La theologie d'eschatologie enseigne que la vie terrestre touche la vie céleste.

Le Missel après Vatican II est plus riche que le précédent concernant le texte des oraisons de défunt. Dans ce missel, il y a beacoup d'oraisons qui correspondent bien à la situation terrestre du défunt. Les textes d'oraisons présentent l'union de l'église avec la famille du défunt, avec ceux qui restent vivants et leur douleur.

La base pour ces textes de prières c'est le mystère pascale du Christ qui touche sa croix et sa résurrection, et qui est la source pour la résurrection de l'homme.

La caractéristique de ces textes de prières pour les défunts sont les oraisons pour les enfants défunts et pour leur parents vivants et les oraisons des personnes dont la foi n'est connue que par Dieu.

Après Vatican II la prière pour le défunt présente l'espoir dans la misericorde divine et fait rendre grâce à Dieu pour la vie terrestre du défunt. Donc, la liturgie des obsèques après Vatican II est une louanges à Dieu. 


\section{Bibliografia:}

Botte B., Les plus anciennes formules de priere pour les morts, w: La maladie et la mort du chretien dans la liturgie, Roma 1975, s. 90-93.

Czerwik S., Modlitwa eucharystyczna, w: W. Świerzawski (red.), Msza Święta. Mysterium Christi, Kraków 1992, s. 274-275.

Decyk J., Rzeczywistość eschatyczna człowieka wedlug modlitw za zmarlych Mszału Rzymskiego Pawła VI, Warszawa 1995.

Góralczyk P., Sens życia, sens śmierci. W petni osobowe spotkanie z Chrystusem, Ząbki 2003.

Goutierre M.-D., Człowiek w obliczu własnej śmierci. Absurd czy zbawienie?, (tłum.) A. Kuryś, Kraków 2001.

Janicki J., Misterium Paschalne w Mszale Rzymkim Pawła VI, Warszawa 1992.

Jungmann J., Missarum Solemnia, t. 3, Paris 1954.

Nadolski B., Liturgika, t. 4, Eucharystia, Poznań 1992.

Nelidow A., Rite des Junerailles des enfants, w: La maladie et la mort du chrétien dans la liturgie, Roma 1975, s. 229-242.

Roguet A., Messe per le esequie dei bambini, „Rivista Liturgica”, 58(1971) nr 3, s. 408-414.

Triacca A., Per una lettura liturgica dei prefazi (pro defunctis) del nuovo Messale Romano, „Rivista Litugica” 58 (1971), nr 3, s. 382 nn.

Turck A., Note sur le finerailles d'efants non baptises, „La Maison-Dieu”, 101 (1970), s. 113-118.

Wardi A., Johnson C., The prefaces of the Roman Missal, Roma 1989. 